\title{
Tingkat Kepuasan Siswa Memanfaatkan Layanan Konseling Individual (Studi Empiris di SMK PGRI Wonoasri Kabupaten Madiun)
}

\author{
Fransisca Mudjijanti \\ Universitas Katolik Widya Mandala Surabaya \\ Email: fransiscamudjijanti@gmail.com
}

\begin{tabular}{l}
\hline Article Info \\
\hline Article History \\
Received: 2020-11-17 \\
Revised: 2021-01-05 \\
Published: 2021-01-13 \\
\\
Keywords: \\
Student Satisfaction Level; \\
Counseling Service \\
Quality.
\end{tabular}

\section{Abstract}

The purpose of this study was to identify and obtain a description of: 1) Students' expectations (level of importance) for individual counseling services; 2) The reality (level of satisfaction) that students receive for individual counseling services; 3) Students' expectations (level of importance) for individual counseling services based on the dimensions of service quality; 4) The reality (level of satisfaction) received by students for individual counseling services based on the dimensions of service quality; 5) There is a gap between the expectations and reality received by students for individual counseling services. The population in this study was 50 students of SMK PGRI Wonoasri Madiun who had participated in individual counseling services in the $2019 / 2020$ academic year. Because the population is small, all members of the population are used as research samples, with a total sampling technique. Data analysis using descriptive statistical techniques. The results of the analysis are: 1) The expectations (level of importance) of students using individual counseling services are in the very important category, namely as much as $72 \%$; 2) The reality (level of satisfaction) received by students using individual counseling services is in the very satisfied category, namely as much as $80 \%$; 3 ) The expectation (level of importance) of students using individual counseling services based on the dimensions of service quality is in the very important category for the dimensions of reliability, empathy, and physical evidence, while the dimensions of responsiveness, and certainty are in the important category; 4) The expectation (level of importance) of students using individual counseling services based on the dimensions of service quality is in the very important category for the dimensions of reliability, empathy, and physical evidence, while the dimensions of responsiveness, and certainty are in the important category; 5) There is a gap between the expectations or level of student interest and the reality or level of student satisfaction using individual counseling services on the dimensions of reliability, empathy, and physical evidence.

\begin{tabular}{l}
\hline Artikel Info \\
\hline Sejarah Artikel \\
Diterima: $2020-11-17$ \\
Direvisi: $2021-01-05$ \\
Dipublikasi: $2021-01-13$
\end{tabular}

Kata kunci:

Tingkat Kepuasan Mahasiswa;

Kualitas Layanan

Konseling.

\begin{abstract}
Abstrak
Tujuan penelitian ini adalah untuk mengetahui dan memperoleh gambaran tentang: 1) Harapan (tingkat kepentingan) siswa atas layanan konseling individual; 2) Kenyataan (tingkat kepuasan) yang diterima siswa atas layanan konseling individual; 3) Harapan (tingkat kepentingan) siswa atas layanan konseling individual berdasarkan dimensi kualitas layanan; 4) Kenyataan (tingkat kepuasan) yang diterima siswa atas layanan konseling individual berdasarkan dimensi kualitas layanan; 5) Adanya gap antara harapan dan kenyataan yang diterima siswa atas layanan konseling individual. Populasi penelitian adalah siswa SMK PGRI Wonoasri Kabupaten Madiun yang pernah mengikuti layanan konseling individual pada tahun pelajaran 2019/2020 berjumlah 50 siswa. Karena jumlah populasi kecil, seluruh anggota populasi dijadikan sampel penelitian, dengan teknik total sampling. Analisis data dengan teknik statistik dekriptif. Hasil analisis adalah : 1) Harapan (tingkat kepentingan) siswa memanfaatkan layanan konseling individual berada pada kategori sangat penting, yaitu sebanyak 72\%; 2) Kenyataan (tingkat kepuasan) yang diterima siswa memanfaatkan layanan konseling individu berada pada kategori sangat memuaskan, yaitu sebanyak 80\%; 3) Harapan (tingkat kepentingan) siswa memanfaatkan layanan konseling individual berdasarkan dimensi kualitas layanan berada pada kategori sangat penting untuk dimensi kehandalan, empati, dan bukti fisik, sedang dimensi daya tanggap, dan kepastian pada kategori penting; 4) Harapan (tingkat kepentingan) siswa memanfaatkan layanan konseling individual berdasarkan dimensi kualitas layanan berada pada kategori sangat penting untuk dimensi kehandalan, empati, dan
\end{abstract}


bukti fisik, sedang dimensi daya tanggap, dan kepastian pada kategori penting; 5) Ada gap antara harapan atau tingkat kepentingan siswa dan kenyataan atau tingkat kepuasan siswa dalam memanfaatkan layanan konseling individual pada dimensi kehandalan, empati, dan bukti fisik.

\section{PENDAHULUAN}

Tujuan pendidikan pada dasarnya bukan hanya diarahkan untuk penguasaan ilmu pengetahuan, akan tetapi juga sebagai tempat bagi peserta didik dalam mengembangkan pribadi secara utuh dan optimal. Siswa di sekolah adalah subjek didik yang memiliki masalah-masalah psikologis. Masalah psikologis tersebut muncul karena siswa sedang mengalami masa-masa transisi dari masa kanakkanak menuju masa remaja hingga remaja akhir. Oleh karena itu, diperlukan sebuah bantuan secara profesional untuk membantu siswa menyelesaikan masalah-masalah tersebut dan membanu siswa untuk berkembang secara optimal. Layanan bantuan tersebut dinamakan layanan konseling khususnya layanan konseling individual. Layanan konseling bertujuan membantu siswa agar dapat menyelesaikan masalah-masalah pribadinya dan agar dapat berkembang secara optimal.

Layanan konseling individual menjadi layanan yang dikhususkan membantu penyelesaian masalah siswa. Selain itu, layanan ini juga dipandang sebagai "jantung hatinya" program Bimbingan dan Konseling. Menurut Prayitno (2009) maksud dari jantung hati yaitu layanan konseling memiliki dampak terhadap layanan yang lainnya. Berdasarkan hal ini dapat terlihat bahwa layanan konseling individual termasuk layanan yang penting. Berdasarkan tujuan tersebut, maka layanan konseling yang diberikan haruslah berkualitas agar siswa dapat merasakan layanan yang diberikan. Ketika siswa merasakan layanan yang berkualitas, maka siswa akan merasa puas terhadap layanan konseling.

Pentingnya peran layanan konseling individual bagi perkembangan siswa, mengharuskan konselor atau guru BK untuk lebih memperhatikan layanan yang telah diberikan. Adanya proses evaluasi terhadap layanan konseling individual menjadi masukan (input) dalam perbaikan program bimbingan dan konseling pada umumnya dan layanan konseling khususnya. Salah satu cara dalam mengevaluasi layanan konseling individual yaitu dengan mengukur kepuasan siswa sebagai pengguna layanan ini. Seperti dikatakan oleh Goodstein dan Grigg dalam Amalia (2016) :"...client satisfaction as an important factor in any overall evaluation of the counseling process". Adanya perubahan ke arah yang lebih baik menjadi harapan umum siswa yang mengikuti layanan konseling individual.

Kepuasan siswa atas layanan konseling individual merupakan perbandingan antara harapan (tingkat kepentingan) terhadap layanan konseling individual dengan kenyataan yang diterima siswa. Siswa diajak untuk memberikan penilaian tentang harapannya terhadap layanan konseling lalu menyampaikan tanggapannya setelah menerima layanan konseling tersebut. Apabila hasil tanggapan sesuai dengan harapan siswa, maka siswa merasa puas, begitu pula sebaliknya. Pada umumnya, harapan siswa mengikuti layanan konseling adalah dapat menghasilkan solusi pribadi dan adanya perubahan kearah yang lebih baik dalam diri siswa. Oleh karena itu, dalam rangka memberikan pelayanan yang berkualitas, penelitian terkait dengan tingkat kepuasan siswa harus dilakukan agar dapat diperoleh gambaran tentang harapan siswa terhadap keberadaan layanan konseling individual dan kenyataan yang diterima siswa atas layanan konseling individual itu. Bila ada gap antara harapan dan kenyataan yang diterima siswa atas layanan konseling individual, pihak yang terkait bisa segera melakukan perbaikan seperlunya.

Berdasarkan latar belakang permasalahan di atas, peneliti merumuskan masalah penelitian sebagai berikut: (1) Bagaimana gambaran harapan (tingkat kepentingan) siswa atas layanan konseling individual di SMK PGRI Wonoasri Kabupaten Madiun? (2) Bagaimana gambaran kenyataan (tingkat kepuasan) yang diterima siswa atas layanan konseling individual di SMK PGRI Wonoasri Kabupaten Madiun ? (3) Bagaimana gambaran harapan (tingkat kepentingan) siswa atas layanan konseling individual di SMK PGRI Wonoasri Kabupaten Madiun dilihat dari dimensi kualitas layanan ? (4) Bagaimana gambaran kenyataan (tingkat kepuasan) yang diterima siswa atas layanan konseling individual di SMK PGRI Wonoasri Kabupaten Madiun dilihat dari dimensi kualitas layanan ? (5) Apakah ada gap antara harapan (tingkat kepentingan) dan kenyataan (tingkat kepuasan) yang diterima siswa atas layanan konseling individual di SMK PGRI Wonoasri Kabupaten Madiun?.

Sejalan dengan rumusan masalah di atas, penelitian ini memiliki tujuan untuk memperoleh gambaran tentang: (1) Harapan (tingkat kepentingan) siswa atas layanan konseling individual di SMK PGRI Wonoasri Kabupaten Madiun. (2) Kenyataan (tingkat kepuasan) yang diterima siswa atas layanan konseling individual di SMK PGRI Wonoasri Kabupaten Madiun. (3) Harapan (tingkat kepentingan) siswa atas layanan konseling individual di SMK PGRI Wonoasri Kabupaten Madiun dilihat dari dimensi kualitas layanan. (4) Kenyataan (tingkat kepuasan) yang diterima siswa atas layanan konseling individual di SMK PGRI Wonoasri Kabupaten Madiun dilihat dari dimensi kualitas layanan. (5) Adanya gap antara harapan (tingkat kepentingan) dan kenyataan (tingkat kepuasan) yang diterima siswa atas layanan konseling individual di SMK PGRI Wonoasri Kabupaten Madiun.

Penelitian yang telah dilakukan sebelumnya dan relevan dengan penelitian ini antara lain yang dilakukan oleh : (a) Amalia, dkk (2016) tentang 
"Kepuasan Siswa terhadap Layanan Konseling Individual (survey pada siswa kelas VIII di SMP Negeri se-Kecamatan Matraman Jakarta Timur)" menunjukkan bahwa sebagian siswa di SMPN 7 Jakarta belum merasa puas terhadap layanan konseling individual yang diberikan. Hal ini disebabkan karena siswa merasa cara yang diberikan konselor dalam membantu menyelesaikan masalah dengan ancaman bukan hal yang tepat, cara layanan konseling yang diberikan tidak ada dampak perubahan dalam diri, konselor terlalu cepat menyimpulkan siswa yang bermasalah. Ketidak puasan siswa terhadap layanan konseling tidak menutup kemungkinan akan menimbulkan keengganan siswa untuk menggunakan kembali layanan konseling, apabila konselor tidak berusaha memperbaiki diri agar kualitas layanan konseling yang diberikan baik dan sesuai harapan siswa. (b) Susilowati (2016) tentang "Kepuasan Siswa Terhadap Layanan Bimbingan dan Konseling di SMKN 1 Badegan Ponorogo" menunjukkan bahwa secara keseluruhan siswa merasa puas terhadap pelayanan bimbingan dan konseling di SMKN 1 Badegan Ponorogo. Tingkat kepuasan siswa terhadap pelayanan bimbingan dan konseling tergolong sedang atau cukup (30\%). Tingkat kepuasan siswa terhadap ketersediaan fasilitas sarana dan prasarana BK tergolong sangat rendah (10\%). Tingkat kepuasan siswa terhadap kapasitas dan kemampuan guru BK tergolong cukup atau sedang (38\%)

\section{a) Kepuasan Siswa atas Layanan Konseling} Individual

Kepuasan dalam bagahasa Inggris disebut satisfaction. Satisfaction berasal dari bahasa latin, satis yang berarti enough atau cukup dan facere yang berarti to do atau melakukan. Dengan kata lain, kepuasan dapat dirasakan pelanggan apabila sanggup memberikan sesuatu yang dicari sampai pada tingkat cukup, Tse \& Wilton dalam Tjiptono (2004) menyatakan bahwa kepuasan atau ketidakpuasan adalah respon seseorang terhadap evaluasi ketidaksesuaian/ diskonfirmasi yang dirasakan antara harapan dan kinerja aktual yang dirasakannya. Sedangkan Rangkuti (2003) mendefinisikan kepuasan sebagai respon pelanggan terhadap ketidaksesuaian antara tingkat kepentingan sebelumnya dan kinerja aktual yang dirasakan setelah pemakaian. Ada kesamaan antara beberapa dimensi di atas, yaitu menyangkut komponen kepuasan (harapan dan kinerja/ hasil yang dirasakan).

b) Kualitas Layanan Konseling

Kepuasan layanan konseling dalam hal ini dapat dilihat dari kualitas layanan konseling, yang berarti kepuasan layanan konseling seperti yang dikemukakan oleh Parasuraman (1985) bahwa kepuasan siswa dalam hal layanan konseling dipengaruhi oleh perbedaan harapan (expectation) dan persepsi terhadap kinerja (performence). Persepsi terhadap kepuasan layanan dapat dilihat dari dimensi kualitas layanan yaitu kehandalan, daya tanggap, kepastian, empati dan berwujud. sedangkan harapan terhadap kepuasan layanan konseling tersebut sebagai tuntutan atau keinginan siswa.

Kepuasan siswa terhadap layanan konseling terpenuhi jika kinerja layanan konseling sesuai harapan siswa, jika kinerja pelayanan konseling tidak memenuhi harapan siswa, maka siswa akan kecewa dan mungkin tidak akan memanfaatkan layanan konseling lagi. Untuk menciptakan kepuasan siswa, pelayanan konseling harus menciptakan dan mengelola kualitas layanan sehingga memperoleh simpati siswa sebagai pihak yang dilayani agar terus memanfaatkan pelayanan konseling.

Kualitas pelayanan konseling akan mendorong terwujudnya kepuasan siswa setelah mereka memanfaatkannya berdasarkan konsep manajemen bahwa "Pelanggan yang puas akan melakukan pembelian ulang pada waktu yang akan datang dan memberitahukan kepada orang lain atas kinerja produk atau jasa yang telah dirasakan" (Fritzsimmons, SA, 1992). Atas dasar analogi tersebut, dalam pelayanan konseling jika siswa memperoleh kepuasan atas pemenuhan harapannya, siswa akan datang lagi meminta pelayanan konseling ketika dia membutuhkannya, selain itu siswa juga akan memberitahukan rasa puasnya kepada siswa yang lain. Kepuasan siswa setelah mendapat pelayanan konseling dapat dijadikan barometer kualitas pelayanan konseling di sekolah.

Dalam hubungannya dengan kualitas, Parasuraman dkk, (1985) mengidentifikasi lima dimensi kualitas pelayanan yaitu reliability, responsiveness, assurance, empathy, dan tangible. Sesuai dengan dimensi kualitas pelayanan tersebut, maka dimensi kualitas layanan konseling yang akan diteliti meliputi kelima dimensi tersebut yang merujuk pada kepuasan siswa, yaitu: 1) Kehandalan (Reliability), kehandalan merupakan kemampuan memberikan pelayanan seperti yang telah dijanjikan dengan segera, akurat, dan memuaskan (Sedarmayanti, 2000). Dalam hal ini konselor berusaha memberikan pelayanan kepada siswa sesuai kesepakatan bersama dengan segera, akurat dan memuaskan. Usaha yang dilakukan konselor berkaitan dengan hal tersebut yaitu konsisten terhadap kesepakatan bersama, sistem dan prosedur pelayanan konseling, taat terhadap prinsip-prinsip konseling, menepati jadwal pertemuan yang disepakati. Dengan kehandalan yang dimiliki konselor dapat memberikan kepercayaan kepada siswa dalam menjalani proses konseling. 2) Daya tanggap (Responsiveness), daya tanggap merupakan kesadaran, kesediaan, kesiapan dan kecepatan serta spontanitas konselor dalam memberikan 
pelayanan konseling kepada siswa sesuai dengan kebutuhan dan masalah siswa. Kesadaran konselor berkaitan dengan permasalahan siswa di sekolah meliputi masalah pribadi, sosial, belajar dan karir, yang terkadang siswa kurang memahami hal tersebut. Maka dengan kesadaran inilah konselor mampu memberikan layanan konseling terhadap siswa yang bermasalah. Kesediaan konselor dalam hal ini berkaitan dengan meluangkan waktunya untuk memberikan layanan kepada siswa seperti salah satu azas bimbingan dan konseling yaitu azas kesukarelaan. Konselor hendaknya dapat memberikan bantuan dengan ikhlas (Prayitno, 2009). Kesiapan yang dimaksud yaitu konselor siap setiap saat dalam membantu siswa memecahkan masalahnya dengan melakukan layanan konseling. Sehingga dengan kesiapan yang dimiliki oleh konselor siswa merasa diperhatikan. Kecepatan konselor dalam memberikan layanan konseling yang efektif sangat dibutuhkan dimulai dari identifikasi dan penentuan sumber masalah. Prayitno (2009) mengatakan bahwa konselor harus cepat memberikan perhatian terhadap apa yang terjadi dan atau mungkin akan terjadi pada peserta didik, serta mengambil tindakan secara tepat untuk mengatasi dan atau mengantisipasi apa yang terjadi dan/atau mungkin terjadi. Daya tanggap juga berhubungan dengan spontanitas. Menurut Latipun (2011) sikap spontanitas konselor merupakan aspek yang sangat penting dalam kegiatan layanan konseling. Jadi kualitas layanan konseling dalam dimensi daya tanggap yaitu konselor dalam memberikan layanan konseling pada siswa harus memiliki kesediaan yang ditandai dengan kesukarelaan, kecepatan dalam arti pelayanan konseling yang diselenggarakan konselor dengan cepat diberikan kepada siswa yang membutuhkan, dan memerlukan spontanitas konselor yang tinggi untuk mengamati perubahan yang dialami siswa baik ketika kegiatan layanan konseling berlangsung maupun setelah kegiatan. 3) Kepastian (Assurance), dalam kriteria ini konseli perlu merasa bahwa dirinya diperhatikan dan dihargai oleh konselor. Oleh karena itu konselor harus memiliki sikap dan perilaku yang positif untuk dapat menghargai dan memperhatikan konseli sebagai individu yang berpotensi, konselor harus bersikap adil kepada siswa. Menurut Suherman (2003) berdasarkan keragaman konseli dan orientasi konselor, secara umum seorang konselor hendaknya menunjukkan sikap dan perilaku sebagai berikut: (a) berusaha menciptakan suasana dan hubungan yang lebih baik; (b) berusaha menjaga sikap objektif terhadap konseli; (c) mengeksplorasi faktor penyebab masalah-masalah psikologis masa lalu maupun masa sekarang; (d) mempertahankan transfer pemahaman perilaku baru yang diperlukan konseli dalam kehidupan sehari-hari; (e) menjadi model atau contoh dalam bersikap sehat dan normal; (f) menyadari kesalahan yang pernah dibuat; (g) dapat dipercaya dan mampu menjaga rahasia; (h) memiliki orientasi diri yang selalu berkembang; (i) ikhlas dalam menjalani profesinya. Pendapat Latipun (2011) konselor maupun konseli harus membangun hubungan yang jujur dan terbuka. Dalam hal ini tidak ada sandiwara dengan jalan menutupi kelemahan atau bukan yang sejatinya. Jadi kualitas layanan konseling dalam dimensi kepastian yaitu konselor memiliki sikap yang mampu membangun keyakinan dan kepercayaan siswa terhadap konselor dalam memberikan layanan konseling. 4) Empati (Emphaty), empati merupakan sikap ikut merasakan dan berfikir ke dalam kepribadian orang lain sehingga tercapai keadaan identifikasi. Rangkuti (2003) empati merupakan rasa peduli memberikan perhatian secara individual, memahami kebutuhan individu serta kemudahan untuk dihubungi. Goleman (1997) menyatakan terdapat 3 (tiga) karakteristik kemampuan seseorang dalam berempati, yaitu: (a) Mampu menerima sudut pandang orang lain; (b) Memiliki kepekaan terhadap perasaan orang lain; (c) Mampu mendengarkan orang lain. Patterson dalam Latipun (2011) beberapa hal yang perlu diperhatikan konselor dalam merespon konseli: (a) Respon harus pendek dan to the point, menangkap esensi dari perasaan dan situasi; (b) Bukan pengulangan dari apa yang orang lain katakan ya, diulangi dalam kata yang berbeda; (c) Harus lebih dalam dari apa yang telah dikatakan, seperti menebak perasaan yang tidak diungkapkan. 5) Bukti Fisik (Tangible), bukti fisik merupakan salah satu dimensi kualitas pelayanan konseling yang mudah dilihat oleh konseli (siswa). Sukardi (2002) mengatakan sarana dan prasarana yang dibutuhkan dalam layanan konseling antara lain sebagai berikut : (a) Sarana terdiri dari alat pengumpul data, alat penyimpan data, perlengkapan teknis; (b) Prasarana terdiri dari ruangan bimbingan dan koneling, anggaran biaya; (c) Penampilan konselor. Dalam hal ini berpenampilan rapi dan menjaga perilaku. Kenyamanan dan merasa aman akan muncul di diri seorang klien apabila konselor memperhatikan penampilan.

c) Mengukur Kepuasan

Dalam penelitian ini, untuk mengukur kepuasan siswa terhadap layanan konseling individual yang telah diterima dengan mengembangkan instrumen kepuasan siswa berdasarkan kualitas pelayanan pengembangan dari teori service quality (SERVQUAL). Parasuraman dkk, (1985) mengidentifikasi lima dimensi kualitas pelayanan yaitu kehandalan (reliability), daya tanggap (responsiveness), kepastian (assurance), empati 
(empathy), dan bukti fisik (tangible).

d) Definisi Layanan Konseling Individual

Sukardi (2002) berpendapat bahwa "konseling perorangan merupakan layanan bimbingan dan konseling yang memungkinkan peserta didik mendapatkan layanan langsung secara tatap muka dengan guru pembimbing (konselor) dalam rangka pembahasan dan pengentasan masalah". Prayitno (2009) menjelaskan bahwa konseling perorangan merupakan layanan konseling yang diselenggarakan oleh seorang konselor terhadap seorang klien dalam rangka pengentasan masalah pribadi klien. Willis (2010) konseling perorangan mempunyai makna spesifik dalam arti pertemuan konselor dengan klien secara individu, dimana terjadi hubungan konseling yang bernuansa rapport, dan konselor berupaya memberikan bantuan untuk pengembangan pribadi klien serta klien dapat mengantisipasi masalah-masalah yang dihadapinya, Layanan konseling individual adalah suatu proses pemberian bantuan secara profesional yang dilakukan oleh konselor kepada konseli dengan tujuan untuk pengentasan masalah, memberikan bantuan dalam merubah sikap dan tingkah laku konseli ke arah yang baik.

e) Tujuan Layanan Konseling Individual

Menurut Prayitno (2009) tujuan konseling perorangan terdiri dari tujuan umum dan tujuan khusus. 1) T ujuan umum konseling perorangan adalah terentaskannya masalah yang dialami klien. 2) Tujuan Khusus, dalam kerangka tujuan umum itu, tujuan khusus layanan konseling individual dapat dirinci dan secara langsung dikaitkan dengan fungsi-fungsi konseling yang secara menyeluruh diembannya antara lain : (a) fungsi pemahaman, (b) fungsi pengentasan, (c) fungsi pengembangan, (d) fungsi pencegahan, (e) fungsi advokasi.

\section{METODE PENELITIAN}

A. Pendekatan Penelitian

Penelitian ini berpola deskriptif yaitu pola penelitian yang digunakan untuk menggambarkan atau menganalisis suatu hasil penelitian tetapi tidak untuk mengambil kesimpulan yang lebih luas (Sugiyono, 2013). Dapat dikatakan bahwa penelitian deskriptif merupakan penelitian yang berusaha mendeskripsikan suatu gejala, peristiwa yang terjadi pada saat sekarang atau masalah aktual.

B. Variabel Penelitian

Tingkat kepuasan siswa menggunakan layanan konseling individual adalah tingkat perasaan siswa setelah membandingkan kinerja layanan konseling atau hasil yang dirasakan dengan harapannya yang dikukur berdasarkan lima dimensi kualitas pelayanan konseling yang dikembangkan menurut pendapat Parasuraman (1985) meliputi dimensi reliability, responsiveness, assurance, empathy, dan tangible.

C. Populasi, Sampel, dan Teknik Sampling

Populasi penelitian ini adalah siswa SMK PGRI Wonoasri Kabupaten Madiun kelas XI dan XII yang pernah mengikuti layanan konseling individual pada tahun pelajaran 2019/2020 yang berjumlah 50 siswa (berdasarkan hasil studi awal dengan angket). Penentuan ukuran sampel penelitian ini ditentukan dengan memperhatilkan saran Roscoe (1982) dalam Sugiyono (2013) bahwa ukuran sampel yang layak dalam penelitian adalah antara 30 sampai dengan 500. Memperhatikan pendapat di atas, maka penelitian ini mengambil seluruh populasi yang berjumlah 50 orang sebagai sampel penelitian, dengan teknik sampling jenuh yaitu semua subjek digunakan sebagai sampel.

D. Instrumen Penelitian

Instrumen untuk mengukur kepuasan siswa memanfaatkan layanan konseling individual menggunakan angket dalam bentuk skala yang dikembangkan mengikuti model skala Likert dengan lima alternatif jawaban sebagai berikut :

Tabel 1. Penskoran Skala Psikologi

\begin{tabular}{cll}
\hline Skor & $\begin{array}{c}\text { Harapan (Tingkat } \\
\text { Kepentingan) }\end{array}$ & $\begin{array}{c}\text { Kenyataan } \\
\text { (Tingkat Kepuasan) }\end{array}$ \\
\hline 5 & Sangat Penting/SP & Sangat Memuaskan/SM \\
\hline 4 & Penting/P & Memuaskan/M \\
\hline 3 & Cukup Penting/CP & Cukup Memuaskan/CM \\
\hline 2 & Kurang Penting/KP & Kurang Memuaskan/KM \\
\hline 1 & Tidak Penting/TP & Tidak Memuaskan/TM \\
\hline
\end{tabular}

E. Teknik Analisis Data

1) Uji Coba Alat Ukur

Pengujian alat ukur menggunakan uji validitas dan reliabilitas. Untuk menguji validitas instrumen dipergunakan teknik korelasi Product Moment dengan ketentuan item valid jika nilai $\mathrm{r}$ hitung $>$ nilai $\mathrm{r}$ kritis 0.3 (Sugiyono, 2013) dan uji reliabilitas instrumen menggunakan teknik Alpha Cronbach dengan ketentuan instrumen reliabel jika nilai Alpha Cronbach hitung > 0.6 (Nurgiyantoro, 2005).

2) Analisis Statistik Deskriptif Persentase

Rumus Analisis deskriptif persentase yang digunakan menurut Sugiyono (2013) adalah sebagai berikut:

$$
\mathrm{P}=\stackrel{\mathrm{n}}{\mathrm{N}}-\mathrm{X} \text { X 100\% }
$$

Keterangan :

$\mathrm{N}$ = jumlah skor yang diharapkan

$\mathrm{n}$ = skor yang diperoleh

$\%=$ tingkat kebehasilan yang dicapai

Hasil perhitungan statistik deskriptif dengan rumus di atas, kemudian dikonsultasikan dengan tabel di bawah ini untuk memperoleh 
gambaran tentang tingkat kepuasan siswa memanfaatkan layanan konseling individual.

Tabel 2. Kategori Persentase Harapan dan Tingkat Kepuasan Siswa

\begin{tabular}{lll}
\hline \multirow{2}{*}{ Persentase } & \multicolumn{2}{c}{ Kategori } \\
\cline { 2 - 3 } & $\begin{array}{c}\text { Harapan } \\
\text { Siswa }\end{array}$ & Tingkat Kepuasan \\
\hline $84 \%-100 \%$ & Sangat Penting & Sangat Memuaskan \\
\hline $68 \%-83 \%$ & Penting & Memuaskan \\
\hline $52 \%-67 \%$ & Kurang Penting & Kurang Memuaskan \\
\hline $36 \%-51 \%$ & Tidak Penting & Tidak Memuaskan \\
\hline $36 \%-51 \%$ & $\begin{array}{l}\text { Sangat Tidak } \\
\text { Penting }\end{array}$ & $\begin{array}{l}\text { Sangat Tidak } \\
\text { Memuaskan }\end{array}$ \\
\hline
\end{tabular}

\section{HASIL DAN PEMBAHASAN}

A. Hasil Penelitian

1) Hasil Uji Validitas dan Reliabilitas

Hasil uji validitas skala harapan siswa yang terdiri dari 32 item terdapat 29 item valid karena nilai $r$ hitung $>$ nilai $r$ kritis (0.3) dan 3 item tidak valid karena nilai $r$ hitung $<$ nilai $r$ kritis (0.3) , sedangkan untuk skala tingkat kepuasan siswa memanfaatkan layanan konseling individual yang terdiri dari 32 item emuanya valid karena nilai $r$ hitung $>$ nilai $r$ kritis (0.3). Hasil uji reliabilitas terhadap skala kepuasan siswa memanfaatkan layanan konseling individual menunjukkan bahwa skala harapan dan skala tingkat kepuasan siswa memanfaatkan layanan konseling adalah reliabel karena memiliki nilai $r$ Alpha Cronbach hitung $>0.6$.

2) Hasil Analisis Statistik Deskriptif Persentase a.Harapan (tingkat kepentingan) siswa terhadap layanan konseling individual.

Tabel 3. Harapan (tingkat kepentingan) Siswa terhadap Layanan Konseling Individu

\begin{tabular}{cclcc}
\hline No & Skor & Kategori & Frek & $\begin{array}{c}\text { Persen } \\
\text { tase }\end{array}$ \\
\hline 1 & $84 \%-100 \%$ & $\begin{array}{l}\text { Sangat } \\
\text { Penting }\end{array}$ & 36 & $72 \%$ \\
\hline 2 & $68 \%-83 \%$ & Penting & 14 & $18 \%$ \\
\hline 3 & $52 \%-67 \%$ & $\begin{array}{l}\text { Cukup } \\
\text { Penting }\end{array}$ & 0 & $0 \%$ \\
\hline 4 & $36 \%-51 \%$ & $\begin{array}{l}\text { Kurang } \\
\text { Penting }\end{array}$ & 0 & $0 \%$ \\
\hline 5 & $20 \%-35 \%$ & $\begin{array}{l}\text { Tidak } \\
\text { Penting }\end{array}$ & 0 & $0 \%$ \\
\hline & Jumlah & 50 & $100 \%$ \\
\hline
\end{tabular}

b. Harapan (tingkat kepentingan) siswa terhadap layanan konseling individual berdasarkan dimensi kualitas layanan.

Tabel 4. Harapan Siswa Memanfaatkan Layanan Konseling Individual Berdasarkan Dimensi Kualitas Layanan

\begin{tabular}{ccccc}
\hline No & Dimensi & Kategori & Frek & $\begin{array}{c}\text { Persen } \\
\text { tase }\end{array}$ \\
\hline 1 & Kehandalan & $\begin{array}{c}\text { Sangat } \\
\text { Penting }\end{array}$ & 27 & $54 \%$ \\
\hline 2 & $\begin{array}{c}\text { Daya } \\
\text { Tanggap }\end{array}$ & Penting & 28 & $56 \%$ \\
\hline
\end{tabular}

\begin{tabular}{ccccc}
\hline 3 & Kepastian & Penting & 26 & $52 \%$ \\
\hline 4 & Empati & $\begin{array}{c}\text { Sangat } \\
\text { Penting }\end{array}$ & 25 & $50 \%$ \\
\hline 5 & Bukti Fisik & $\begin{array}{c}\text { Sangat } \\
\text { Penting }\end{array}$ & 25 & $50 \%$ \\
\hline & $\begin{array}{c}\text { c. Kenyataan } \\
\text { memanfaatkan layanan konseling individual } \\
\text { Tabel 5. Tingkat Kepuasan Siswa Memanfaatkan } \\
\text { Layanan Konseling Individual }\end{array}$ & $\begin{array}{c}\text { kepuasan) } \\
\text { Siswa }\end{array}$ \\
\hline $\begin{array}{c}\text { N } \\
\text { o }\end{array}$ & Skor & Kategori & Frek & $\begin{array}{c}\text { Persen } \\
\text { tase }\end{array}$ \\
\hline 1 & $84 \%-100 \%$ & $\begin{array}{l}\text { Sangat } \\
\text { Memuaskan }\end{array}$ & 40 & $80 \%$ \\
\hline 2 & $68 \%-83 \%$ & Memuaskan & 10 & $20 \%$ \\
\hline 3 & $52 \%-67 \%$ & $\begin{array}{l}\text { Cukup } \\
\text { Memuaskan }\end{array}$ & 0 & $0 \%$ \\
\hline 4 & $36 \%-51 \%$ & $\begin{array}{l}\text { Kurang } \\
\text { Memuaskan }\end{array}$ & 0 & $0 \%$ \\
\hline 5 & $20 \%-35 \%$ & $\begin{array}{l}\text { Tidak } \\
\text { Memuaskan }\end{array}$ & 0 & $0 \%$ \\
\hline & Jumlah & $\mathbf{5 0}$ & $\mathbf{1 0 0 \%}$ \\
\hline
\end{tabular}

d. Kenyataan yang diterima atau tingkat kepuasan siswa memanfaatkan layanan konseling individual berdasarkan dimensi kualitas layanan.

Tabel 6. Tingkat Kepuasan Siswa Memanfaatkan Layanan Konseling Individual Berdasarkan Dimensi Kualitas Layanan

\begin{tabular}{clccl}
\hline No & Dimensi & Frek & $\begin{array}{c}\text { Persen } \\
\text { tase }\end{array}$ & Kategori \\
\hline 1 & Kehandalan & 28 & $56 \%$ & Memuaskan \\
\hline 2 & $\begin{array}{l}\text { Daya } \\
\text { Tanggap }\end{array}$ & 28 & $56 \%$ & Memuaskan \\
\hline 3 & Kepastian & 24 & $48 \%$ & $\begin{array}{l}\text { Sangat } \\
\text { memuaskan }\end{array}$ \\
\hline 4 & Empati & 25 & $50 \%$ & Memuaskan \\
\hline 5 & Bukti Fisik & 25 & $50 \%$ & Memuaskan \\
\hline
\end{tabular}

3) Perbandingan antara kategori harapan (tingkat kepentingan) dan kenyataan (tingkat kepuasan) siswa dalam memanfaatkan layanan konseling individual berdasarkan dimensi pelayanan

Tabel 7. Perbandingan Kategori Harapan dan Kenyataan Berdasarkan Dimensi Kualitas Layanan

\begin{tabular}{cllll}
\hline No & Dimensi & Harapan & Kenyataan & $\begin{array}{c}\text { Keterang } \\
\text { an }\end{array}$ \\
\hline 1 & Kehandalan & $\begin{array}{l}\text { Sangat } \\
\text { Penting }\end{array}$ & Memuaskan & $\begin{array}{l}\text { Di bawah } \\
\text { harapan }\end{array}$ \\
\hline 2 & $\begin{array}{l}\text { Daya } \\
\text { Tanggap }\end{array}$ & Penting & Memuaskan & $\begin{array}{l}\text { Sesuai } \\
\text { harapan }\end{array}$ \\
\hline 3 & Kepastian & Penting & $\begin{array}{l}\text { Sangat } \\
\text { memuaskan }\end{array}$ & $\begin{array}{l}\text { Melampaui } \\
\text { harapan }\end{array}$ \\
\hline 4 & Empati & $\begin{array}{l}\text { Sangat } \\
\text { Penting }\end{array}$ & Memuaskan & $\begin{array}{l}\text { Di bawah } \\
\text { harapan }\end{array}$ \\
\hline 5 & Bukti Fisik & $\begin{array}{l}\text { Sangat } \\
\text { Penting }\end{array}$ & Memuaskan & $\begin{array}{l}\text { Di bawah } \\
\text { harapan }\end{array}$ \\
\hline
\end{tabular}




\section{B. Pembahasan}

Tabel 3 di atas menunjukkan bahwa harapan (tingkat kepentingan) siswa terhadap layanan konseling individual sebanyak 36 siswa atau 72\% dari jumlah responden pada kategori sangat penting, 14 siswa atau $18 \%$ siswa memiliki harapan terhadap layanan konseling individual pada kategori penting. Jadi dapat disimpulkan bahwa kecenderungan harapan atau tingkat kepentingan siswa terhadap layanan konseling individual berada pada kategori sangat sangat penting.

Tabel 4 menggambarkan bahwa siswa memiliki kecenderungan tingkat kepentingan pada kategori sangat penting atas dimensi kehandalan, empati, dan bukti fisik, sedang atas dimensi daya tanggap, dan kepastian pada kategori penting. Hal ini menunjukkan bahwa siswa sangat mengharapkan ketepatan dan kesesuaian layanan yang diberikan oleh konselor dalam memberikan bantuan kepada siswa. Selain itu dengan kehandalan yang dimiliki, konselor dapat memberikan kepercayaan kepada siswa dalam menjalani proses konseling. Bagi siswa, dimensi empati sangat penting di dalam pelayanan konseling, karena dengan empati yang ditunjukkan konselor, peserta didik (konseli) merasa ada yang memahami dirinya dan masalahnya. Bukti fisik juga menjadi dimensi yang sangat penting bagi siswa dalam pelayanan konseling. Ruang konseling, ruang tamu, ruang konsultasi, ruang diskusi, ruang dokumentasi dan penampilan seorang konselor sangat menentukan bagi seseorang yang akan melakukan konseling. Kenyamanan dan perasaan aman akan muncul dalam diri seorang konseli apabila ruang konseling yang tersedia memadai dan konselor memperhatikan penampilannya (berpenampilan rapi dan menjaga perilaku). Selain itu dimensi kehandalan dan daya tanggap juga penting bagi siswa dalam pelayanan konseling karena konselor yang memiliki kehandalan mampu bersikap dan berperilaku yang dapat dijadikan model atau teladan bagi siswa atau orang lain, mampu membangun keyakinan dan kepercayaan siswa terhadap konselor dalam memberikan layanan konseling. Daya tanggap juga penting bagi siswa dalam pelayanan konseling karena dengan daya tanggap konselor memiliki kesadaran, kesediaan, kesiapan dan kecepatan serta spontanitas dalam memberikan pelayanan konseling kepada siswa sesuai dengan kebutuhan dan masalah siswa

Tabel 5 menggambarkan bahwa tingkat kepuasan siswa dalam memanfaatkan layanan konseling individual sebanyak 40 siswa atau $80 \%$ dari jumlah responden pada kategori sangat memuaskan dan 10 siswa atau 20\% dari jumlah responden pada kategori memuaskan. Jadi dapat diketahui bahwa kenyataan yang diterima siswa atau tingkat kepuasan siswa dalam memanfaatkan layanan konseling individual berada pada kategori sangat memuaskan.

Tabel 6 menggambarkan bahwa tingkat kepuasan siswa memanfaatkan layanan konseling individual atas dimensi kehandalan, daya tanggap, empati, bukti fisik berada pada kategori memuaskan dan pada kategori sangat memuaskan atas dimensi kepastian.

Tabel 7 menggambarkan masih adanya gap antara harapan atau tingkat kepentingan siswa dan kenyataan atau tingkat kepuasan siswa dalam memanfaatkan layanan konseling individual atas dimensi kehandalan, empati, dan bukti fisik. Hal ini mengindikasikan bahwa tingkat kepuasan siswa belum maksimal, karena masih berada di bawah harapan siswa. Oleh karena itu pada dimensi tersebut konselor masih perlu meningkatkan lagi kinerjanya meskipun sudah dalam kategori memuaskan. Kenyataan yang diterima siswa atau tingkat kepuasan siswa pada dimensi daya tanggap sudah sesuai harapan siswa. Sedangkan kenyataan yang diterima siswa atau tingkat kepuasan siswa pada dimensi kepastian telah melampaui harapannya.

\section{SIMPULAN DAN SARAN}

\section{A. Simpulan}

1) Harapan (tingkat kepentingan) siswa memanfaatkan layanan konseling individual berada pada kategori sangat penting.

2) Kenyataan (tingkat kepuasan) siswa memanfaatkan layanan konseling individual berada pada kategori sangat memuaskan.

3) Harapan (tingkat kepentingan) siswa dalam memanfaatkan layanan konseling individual berdasarkan dimensi kualitas layanan berada pada kategori sangat penting atas dimensi kehandalan, empati, dan bukti fisik, sedang dimensi daya tanggap, dan kepastian pada kategori penting.

4) Ada gap antara harapan atau tingkat kepentingan siswa dan kenyataan atau tingkat kepuasan siswa memanfaatkan layanan konseling individual pada dimensi kehandalan, empati, dan bukti fisik Ada gap antara harapan atau tingkat kepentingan siswa dan kenyataan atau tingkat kepuasan siswa memanfaatkan layanan konseling individual pada dimensi kehandalan, empati, dan bukti fisik.

\section{B. Saran}

1) Bagi konselor perlu meningkatkan kualitas layanan konseling individual pada dimensi kehandalan, empati, dan bukti fisik agar dapat memenuhi harapan siswa, antara lain dengan mengikuti workshop trainning skill counseling.

2) Konselor hendaknya mempertahankan dan meningkatkan kinerjanya atas dimensi daya tanggap, dengan tetap bersikap responsif, peka terhadap permasalahan siswa.

3) Konselor hendaknya tetap mempertahankan kinerjanya atas dimensi kepastian karena layanan konseling individual saat ini telah mampu melampaui harapan siswa, dengan selalu bersikap konsisten, tidak plin plan, menepati waktu yang telah disepakati bersama 


\section{DAFTAR RUJUKAN}

Amalia, Retno Ficky, dkk. 2016. Kepuasan Siswa terhadap Layanan Konseling Individual (survey pada siswa kelas VIII di SMP Negeri seKecamatan Matraman Jakarta Timur). Jurnal. Diterbitkan pada Jurnal Bimbingan dan Konseling Insight 5 (1). Jakarta : FIP UNJ

Fritzsimons, J.JA dan Sullivan, RS. 1992. Service Operation Management. New York : Mc.Graw. Hill.

Goleman, Daniel. 1997. Emotional Intelligence (Kecerdasan Emosional); Mengapa EI Lebih Penting daripada IQ. Jakarta : PT Gramedia Pustaka Utama.

Latipun. 2011. Psikologi Konseling. Jakarta : Ghalia Indonesia

Parasuraman, et.al.1985. A Conceptual model of Service Quality and its Implications For Future Research. Jurnal of Marketing. Vol.49 (Full). pp. 41-50

Prayitno. 2009. Dasar-dasar Bimbingan dan Konseling di Sekolah. Jakarta : PT. Rineka Cipta

Rangkuti, Fredy. 2003. Measuring Customer Satisfaction, Teknik Mengukur dan Strategi Meningkatkan Kepuasan Pelanggan. Jakarta : PT Gramedia
Sedarmayanti. 2000. Restrukturisasi dan Pemberdayaan Organisasi untuk Menghadapi Dinamika Perubahan Lingkungan. Bandung : Mandar Maju

Sugiyono. 2013. Metode Penelitian Kuantitatif, Kualitatif, dan R\&D. Bandung: AFABETA, CV

Suherman, AS. 2003.Makalah : Kompetensi dan Aspek Etik Profesional Konselor Masa Depan. Bandung : ABKIN dan Universitas Pendidikan Indonesia (UPI)

Sukardi, Dewa Ketut. 2002. Proses Bimbingan dan Konseling di Sekolah. Jakarta: Rineka Cipta.

Susilowati, Any. 2014. Kepuasan Siswa Terhadap Layanan Bimbingan dan Konseling di

SMKN 1 Badegan Ponorogo. Jurnal : Diterbitkan pada Jurnal Hisbah 11 (1), Juni 2014,e-ISSN-2581061181.Yogyakarta : UIN Sunan Kalijaga

Tjiptono, Fandy. 2004. Manajemen Jasa. Yogjakarta. Andi Offset

Wilis, Sofyan S. 2010. Konseling Individual Teori dan Praktek. Bandung : Alfabeta 